ISSN (Print) : :1412-7601

ISSN (Online) : 2654-8712

Volume 7, No.1 Maret 2021

EKONOBIS

http://www.ekonobis.unram.ac.id

\title{
ANALISIS PENELUSURAN ALUMNI (TRACER STUDY) PADA PENGGUNA ALUMNI PROGRAM STUDI IESP FAKULTAS EKONOMI DAN BISNIS UNIVERSITAS MATARAM LULUSAN TAHUN 2014-2019
}

Akung Daeng, Ihsan Rois, Ade Paranata.

Universitas Mataram

\begin{tabular}{l}
\hline A RTICLE INFO \\
\hline Keywords: \\
Alumni user responses, \\
Alumni expertise, IESP \\
Program Study
\end{tabular}

Program Study
ABSTRACT : The objectives of this study are 1) How is the suitability of the science and skills obtained in the IESP Program Study with the demands of graduate expertise with the employment market for IESP's alumni, 2) How do IESP's alumni users respond to the expertise of IESP's alumni in the employment market. The research method was carried out by descriptive evaluative. The research subjects were 100 alumni users and graduates of the IESP Department, Faculty of Economics and Business, University of Mataram in 2014-2019. The data analysis technique used in this research is descriptive analysis with a quantitative approach to illustrate the relevance of the alumni expertise obtained in the IESP Program Study with expertise in the employment market of the alumni of the IESP Program Study. The results showed that 71\% of the IESP's Alumni took their study period of 4 years, this means that the study period of students in the IESP department is mostly on time, and is a success for the study program in managing the IESP department, and for the waiting period for IESP's alumni to Getting a job is relatively short, which is less than 6 months as many as $76 \%$ of the alumni,. The assessment of alumni users on the performance of graduates (alumni) of the IESP Program Study where the highest alumni performance according to alumni users who give very good scores (SB) is Alumni Communication by alumni as much as $26 \%$ of users, while users who give good scores $(B)$ are the highest for Use of IT Alumni with good scores (B) as much as $82 \%$
Kata Kunci :

Tanggapan pengguna alumni, Keahlian alumni, Program Studi IESP

ABSTRAK: Tujuan dari penelitian ini adalah 1). Bagaimana kesesuaian keilmuan dan skill yang diperoleh di program studi IESP dengan tuntutan keahlian lulusan dengan dunia kerja alumni jurusan IESP, 2) Bagaimana tanggapan pengguna alumni IESP terhadap keahlian alumni IESP di dunia kerja. Metode penelitian dalam penelitian ini dilakukan dengan deskriptif evaluatif. Subjek penelitian adalah pengguna alumni dan Iulusan Jurusan IESP Fakultas Ekonomi dan Bisnis Universitas Mataram tahun 20142019 sebanyak 100 orang alumni. Teknik analisis data yang digunakan dalam penelitian ini adalah analisis deskriptif dengan pendekatan kuantitatif untuk memberi gambaran relevansi keahlian alumni yang didapat pada program studi IESP dengan keahlian di dunia kerja pada alumni program studi IESP. Hasil Penelitian menunjukkan bahwa Alumni IESP menumpuh masa studi dalam jangka waktu 4 tahun sebanyak $71 \%$ alumni, hal ini berarti masa studi mahasiswa di jurusan IESP sebagian besar tepat pada waktu dan menjadi keberhasilan bagi program studi dalam mengelola jurusan IESP dan untuk masa tunggu alumni IESP untuk mendapatkan pekerjaan relatif singkat yaitu kurang dari 6 bulan sebanyak $76 \%$ alumni. Penilaian pengguna alumni terhadap kinerja lulusan (alumni) program studi IESP dimana kinerja alumni yang paling tinggi menurut pengguna alumni yang memberikan nilai sangat baik (SB) adalah Komunikasi Alumni oleh alumni sebanyak $26 \%$ pengguna, sedangkan pengguna yang memberikan nilai baik (B) tertinggi untuk Penggunaan IT Alumni dengan nilai baik (B) sebanyak $82 \%$

Corresponding Author:

Alamat : Program Studi Ekonomi Pembangunan, Fakultas Ekonomi dan Bisnis, Universitas Mataram, Jln. Majapahit No. 62 Mataram.

e-mail:akungdaeng@unram.ac.id 


\section{PENDAHULUAN}

Latar Belakang

Pendidikan tinggi saat ini sangat dibutuhkan oleh masyarakat untuk menghadapi persaingan di tingkat nasional maupun di daerah, era persaingan saat ini membutuhkan kompetensi dan lulusan perguruan tinggi yang berkualitas untuk dapat memenangkan persaingan yang sejalan dengan tujuan pendidikan tinggi yaitu menyiapkan peserta didik menjadi anggota masyarakat yang memiliki kemampuan akademik dan/atau profesional yang dapat menerapkan, mengembangkan dan/atau memperkaya khasanah ilmu pengetahuan dan teknologi. Peran perguruan tinggi sangat penting dalam meningkatkan pembangunan sumber daya manusia agar dapat bersaing dan berkompetisi di berbagai sector ekonomi di Nusa Tenggara Barat. Dunia kerja di Nusa Tenggara Barat membutuhkan lebih banyak lagi sumber daya manusia yang memiliki kualifikasi pendidikan sarjana yang memiliki kemampuan dan keahlian dibidang ekonomi terutama keahlian pada bidang ekonomi pembangunan untuk dapat menggerakkan pertumbuhan ekonomi di daerah.

Keberhasilan Pendidikan Tinggi adalah aspek relevansi, yaitu ketika mampu menghasilkan lulusan yang memiliki daya saing dan siap berkiprah dalam pembangunan. Daya saing lulusan yang ditunjukkan melalui masa tunggu mendapatkan pekerjaan pertama, keberhasilan lulusan berkompetisi dalam seleksi, dan gaji yang diperoleh. Relevansi (kesesuaian) pendidikan lulusan ini ditunjukkan melalui profil pekerjaan (macam dan tempat pekerjaan), relevansi pekerjaan dengan latar belakang pendidikan, manfaat mata kuliah yang diprogram dalam pekerjaan, saran lulusan untuk perbaikan kompetensi lulusan. Selain itu, relevansi pendidikan juga ditunjukkan melalui pendapat pengguna lulusan tentang kepuasan pengguna lulusan, kompetensi lulusan dan saran lulusan untuk perbaikan kompetensi lulusan.

Fakultas Ekonomi dan Bisnis Universitas Mataram merupakan Fakultas tertua kedua di Universitas Mataram dan dibuka pada tanggal 17 Nopember 1963. Pada saat itu, Fakultas Ekonomi dan Bisnis hanya memiliki satu Program Studi yaitu Program Studi Ekonomi Umum. Program Studi Ekonomi Umum ini kemudian berubah namanya menjadi Program Studi IImu Ekonomi dan Studi Pembangunan pada tahun 1984 dengan SK Dirjen Dikti Nomor 
49/DIKTI/KEP/1984. Pada tahun 1996 nama Program Studi ini berubah menjadi Program Studi Ekonomi Pembangunan berdasarkan SK Dirjen Dikti Nomor 232/DIKTI/KEP/1996. Pada tanggal 20 Desember 1998 Fakultas Ekonomi dan Bisnis Universitas Mataram memperoleh sertifikat akreditasi dengan Peringkat Akreditasi C, berdasarkan surat keputusan Badan Akreditasi Nasional (BAN) Perguruan Tinggi dengan SK Nomor 252/Ak-II.1/UMWIEP/XII/1996. Pada tahun 2004 Program Studi Ekonomi Pembangunan mendapat "Akreditasi B" dari Badan Akreditasi Nasional Perguruan Tinggi (BAN-PT). Pada tahun 2011 Program Studi Ekonomi Pembangunan kembali meraih "Akreditasi B" dari Badan Akreditasi Nasional Perguruan Tinggi (BANPT)

Jurusan IESP ini mempunyai Visi untuk menghasilkan tenaga terdidik yang mampu pada berbagai fleksibilitas, unggul, mandiri, berkepribadian nasional, dan religious, dimana Visi tersebut kemudian dijabarkan dalam Misi: (1). Menyelenggarakan pendidikan, penelitian, pengabdian kepada masyarakat dalam rangka membentuk tenaga kerja dengan berbagai fleksibilitas yang handal diberbagai bidang pembangunan. (2). Mengembangkan sistem pendidikan yang mampu membekali dengan keahlian dibidang yang memiliki fleksibilitas, kearifan, kepribadian nasional, responsif terhadap perkembangan IPTEKS. (3). Membangun budaya akademik yang mendorong pertumbuhan nurani lulusan dengan berbagai fleksibilitas. (4). Memantapkan sistem kelembagaan dan jejaring yang menunjang fungsi Jurusan IESP

Kurikulum yang disusun oleh Jurusan IESP dinilai memadai dalam membekali mahasiswa memasuki dunia kerja, masih ada beberapa aspek yang harus diperbaiki. Aspek-aspek tersebut adalah: peningkatan keterampilan berwirausaha dan kemampuan penguasaan teknologi informasi, dua aspek tersebut dinilai oleh user alumni Jurusan IESP belum begitu memadai. Namun dengan perbaikan kurikulum yang memfokuskan pada kedua aspek tersebut, maka diharapkan di masa yang akan datang mampu mencetak lulusan yang berkompeten yang mampu bersaing di dunia kerja.

Untuk mengetahui sejauh mana lulusan Jurusan IESP dapat bermanfaat bagi masyarakat dengan melihat relevansi kurikulum terutama mata kuliah yang ditawarkan dengan kebutuhan dunia kerja (kemampuan dan skill) oleh karena itu maka dibutuhkan penelitian yang berjudul 
"Analisis Penelusuran Alumni (Tracer

Study) Pada Pengguna Alumni Program

Studi IESP Fakultas Ekonomi Dan Bisnis

Universitas Mataram Lulusan Tahun 2014-

2019"

\section{Identifikasi Masalah}

1. Pekerjaan yang dilakukan oleh alumni IESP didunia kerja seringkali tidak sesuai dengan konsentrasi pada kurikulum di Pogram Studi IESP.

2. Adanya permasalahan kesesuaian antara konsentrasi pada kurikulum di Pogram Studi IESP dengan kemampuan yang dibutuhkan di dunia kerja.

3. Adanya berbagai kendala yang dihadapi alumni jurusan IESP di dalam dunia kerja.

4. Kompetensi yang dibutuhkan dalam dunia kerja terkadang tidak mampu tidak sesuai dengan Keahlian di Pogram Studi IESP.

\section{Batasan Masalah}

Dalam penelitian ini hanya membatasi masalah pada alumni dan pengguna alumni Prodi IESP dengan tuntutan keahlian lulusan dalam bidang pekerjaan di masyarakat dan kompetensi yang dibutuhkan dalam dunia kerja.

\section{Rumusan Masalah}

1. Bagaimana kesesuaian Konsentrasi pada kurikulum di dalam program studi IESP dengan tuntutan keahlian Iulusan dengan dunia kerja alumni jurusan IESP.

2. Konsentrasi pada kurikulum program studi IESP apakah yang paling mendukung alumni IESP yang paling sesuai dengan tuntutan keahlian di dunia kerja.

\section{Tujuan Penelitian}

1. Untuk menganalisisBagaimana kesesuaian Konsentrasi pada kurikulum di dalam program studi IESP dengan tuntutan keahlian lulusan dengan dunia kerja alumni jurusan IESP.

2. Untuk menganalisisKonsentrasi pada kurikulum program studi IESP apakah yang paling mendukung alumni IESP yang paling sesuai dengan tuntutan keahlian di dunia kerja.

\section{Manfaat Penelitian}

Penelitian ini diharapkan memberikan manfaat untuk mendapatkan umpan balik tentang sistem atau proses pembelajaran teruatam kurikulum (konsentrasi) yang ditawarkan pada program studi IESP dengan tuntutan di dunia kerja.

\section{KAJIAN PUSTAKA}

\section{Penelitian Terdahulu}

Mariyanti (1998) melakukan penelitian dengan judul "Penelusuran kesesuaian program studi dengan bidang pekerjaan 
para lulusan fakutas ekonomi Universitas

Trisaksi jurusan ekonomi pembangunan tahun 1997/1998". Permasalahan dalam penelitian ini menitik beratkan pada berapa lama para lulusan fakutas ekonomi Universitas Trisaksi tahun 1997/1998 jurusan IESP mendapatkan pekerjaan ,apakah para lulusan fakutas ekonomi Universitas Trisaksi jurusan IESP tahun 1997/1998 dalam mendapatkan pekerjaan sesuai dengan bidang ilmu yang di peroleh pada waktu kuliah, apakah para lulusan fakutas ekonomi Universitas Trisaksi tahun 1997/1998 dalam mendapatkan pekerjaan sesui dengan konsentrasi yang diambil pada waktu kuliah, dan apakah mata kuliah yang diperoleh pada waktu kuliah mendukung bidang pekerjaan para lulusan fakutas ekonomi Universitas Trisaksi jurusan IESP. Hasil penelitiannya menunjukkan bahwa Para lulusan tahun 1997/1998 Fakultas Ekonomi Universitas Trisakti jurusan Ekonomi Pembangunan dalam bekerja, bidang pekerjaannya tidak sesuai dengan konsentrasi yang diambil sewaktu masih kuliah di Fakultas Ekonomi jurusan Ekonomi Pembangunan. Dilihat dan pekerjaan responden menurut konsentrasi yang diambil maka dapat disimpulkan bahwa mereka yang bekerja di Badan Usaha Milik Negara dan Perusahaan swasta Nasional maupun yang berwiraswasta di dominasi oleh responden yang mengambil konsentrasi Ekonomi Moneter. Hampir $50 \%$ responden mengatakan bahwa Matakuliah yang di dapatkan sewaktu masih kuliah di Fakultas jurusaniJurusan Ekonomi Pembangunan kurang menunjang Pekerjaannya dan kurang lebih sebesar 35 persen dari responden mengatakan tidak menunjang pekerjaan responden sekarang, sedangkan mata kuliah yang dititik beratkan pada waktu kuliah di jurusan ekonomi pembangunan kurang mendukung dan tidak mendukung pekerjaan responden. Ternyata bidang pekerjaan yang dia tekuni sekarang ini tidak sesuai dengan bidang ilmu yang didapatkan pada waktu kuliah di fakultas ekonomi jurusan ekonomi pembangunan universitas trisakti yaitu sebesar 64,2 persen. Dan para lulusan Fakultas Ekonomi Jurusan Ekonomi Pembangunan mayoritas mereka cepat mendapatkan pekerjaan, misalnya lama waktu menunggu dari setelah lulus hanya menunggu selama 0-6 bulan sebesar 75 responden atau sebesar 72,1 Persen.

$$
\text { Suharti dan Laksono }
$$
melakukan penelitian studi penelusuran dengan judul "Studi penelusuran terhadap alumni program studi manajemen fakultas ekonomika dan bisnis universitas Kristen satya wacana". Permasalahan dalam 
penelitian ini adalah lamanya masa tunggu alumni jurusan manajemen fakultas ekonomika dan bisnis Universitas Kristen Satya Wacana untuk memperoleh pekerjaan, kesesuaian bidang ilmu dengan bidang pekerjaan, kompetensi alumni dengan tuntutan dunia kerja dan pengembangan kurikulum program studi kedepan. Hasil penelitian menunjukkan bahwa alumni jurusan manajemen fakultas ekonomika dan bisnis Universitas Kristen Satya Wacana memiliki masa tunggu kerja yang normal sekitar tiga bulan, kurikulum yang dikembangkan program studi sudah baik dimana semua mata kuliah dasar inti yang diselenggarakan bermanfaat dalam menunjang pekerjaan mereka dan kompetensi hard dan soft skill alumni yang diperoleh selama kuliah sangat baik dimana kompetensi soft skill lebih tinggi dibandingkan kompetensi hard skill.

Penelitian yang dilakukan oleh Soemantri,Dkk (2010) Dengan Judul "Kajian Relevansi Lulusan Jurusan Pendidikan Geografi Uny Tahun 2005 2009" Penelitian ini bertujuan untuk mengidentifikasikan profil lulusan Jurusan Pendidikan Geografi tahun 2005-2009 dan relevansi kurikulum di Jurusan Pendidikan Geografi UNY dengan kebutuhan pasar kerja. Profil lulusan meliputi : masa tunggu lulusan, persen lulusan yang sudah bekerja, dan penghasilan pertama yang diperoleh. Metode penelitian yang digunakan dalam penelitian ini adalah metode deskriptif dengan pendekatan survei. Subjek penelitian ini adalah lulusan Jurusan Pendidikan Geografi FISE-UNY tahun 2005-2009 sebanyak 246 orang. Hasil pengumpulan data dengan teknik angket dan dokumentasi diperoleh balikan sejumlah 95 orang. Teknik analisis data yang digunakan adalah analisis deskriptif dengan persentase kemudian dideskripsikan sebagai gambaran profil dari Iulusan. Hasil penelitian diperoleh 1. Profil lulusan Jurusan Pendidikan Geografi tahun 2005-2009 sebagai berikut: a. sebanyak 77,40 persen lulusan sudah memperoleh pekerjaan kurang dari delapan bulan, Hanya 5,38 persen Iulusan memperoleh pekerjaan pertama lebih dari 32 bulan, dan 11,50 persen lulusan memperoleh pekerjaan sebelum yudisium. b. Persentase lulusan yang sudah bekerja sebagai Guru yaitu 80 persen dan non Guru 17,89 persen, serta hanya 2,11 persen belum bekerja. c. Penghasilan pertama yang diperoleh sebanyak 52 persen kurang dari satu juta, dan 47 persen lulusan antara Rp. 1.081.000 sampai Rp 2.060.000. 2 . Relevansi kurikulum dengan kebutuhan pasar kerja diperoleh hasil sebanyak 78,95 persen lulusan merasa memiliki life skill 
untuk jenis pekerjaan yang sesuai latar pendidikan dan 78,79 persen lulusan menyatakan materi kuliah yang diberikan di Jurusan Pendidikan Geografi sudah sesuai kebutuhan pekerjaan yang sesuai latar belakang pendidikan.

\section{Pengertian Kurikulum}

Kurikulum adalah rencana tertulis tentang kemampuan yang harus dimiliki berdasarkan standar nasional, materi yang perlu dipelajari dan pengalaman belajar yang harus dijalani oleh peserta didik untuk mencapai kemampuan yang telah direncanakan, dan evaluasi yang perlu dilakukan untuk menentukan tingkat pencapaian kemampuan peserta didik, serta seperangkat peraturan yang berkenaan dengan pengalaman belajar peserta didik dalam mengembangkan potensi dirinya pada satuan pendidikan tertentu (Hamalik, 2008; 91).

Suatu kurikulum disusun untuk mewujudkan tujuan pendidikan nasional dengan memperhatikan tahap perkembangan peserta didik dan kesesuaian dengan lingkungan, kebutuhan pembangunan nasional, perkembangan ilmu pengetahuan dan teknologi serta kesenian, sesuai dengan jenis dan jenjang masing-masing satuan pendidikan (Hamalik, 2008; 92).

\section{Fungsi Kurikulum}

Menurut Hamalik fungsi kurikulum adalah sebagai berikut (Hamalik,2008) :

a. Fungsi Integrasi, kurikulum sebagai alat pendidikan harus mampu menghasilkan pribadi-pribadi yang utuh. Peseta didik pada dasarnya merupakan anggota dan bagian integral masyarakat ke jenjang yang lebih tinggi.

b. Fungsi Penyesuaian, kurikulum sebagai alat pendidikan harus mampu mengarahkan peserta didik memiliki sifat well adjust, yaitu mampu menyesuaikan dirinya dengan lingkungan, baik lingkungan fisik maupun lingkungan social

c. Fungsi Diferensiasi, kurikulum sebagai alat pendidikan harus mampu memberikan layanan terhadap perbedaan individu peserta didik. Setiap peserta didik memiliki perbedaan baik dari aspek fisik maupun psikis.

d. Fungsi Diagnostik, kurikulum sebagai alat pendidikan harus mampu membantu dan mengarahkan peserta didik untuk dapat memahami dan menerima potensi dan kelemahankelemahan yang ada pada dirinya masing-masing

e. Fungsi Pemilihan, kurikulum sebagai alat pendidikan harus mampu 
memberikan kesempatan kepada peserta didik untuk memilih programprogram belajar yang sesuai dengan kemampaun dan minatnya.

f. Fungsi Persiapan, kurikulum sebagai alat pendidikan harus mampu mempersiapkan peserta didiknya melanjutkan studi ke jenjang pendidikan yang lebih tinggi.

\section{Model-model Kurikulum}

a. Model Kurikulum subjek akademik, kurikulum ini mennekankan pada isi atau materi berkaitan dengan ilmu pengetahuan yang diambil dari disiplindisiplin ilmu

b. Model Kurukulum teknologis, kurikulum ini mennekankan pada isi kurikulum tetapi isinya bukan diambil atau menunjukkan disiplin ilmu tetapi berupa kompetensi atau kecakapan dan keterampilan

c. Model Kurikulum humanistik, model kurikulum ini menekankan pada pengembangan kepribadian secara utuh dan seimbang antara perkembangan segi intelektual, afektif dengan psikomotor.

d. Model Kurikulum rekonstruksi sosial, model kurikulum ini menekankan pemecahan permasalahanpermasalahan yang secara nyata dihadapi masyarakat yang menekankan pembelajaran kooperatif dalam berbagai kegiatan kelompok. (Tim Pengembang IImu Pendidikan UPI,2007)

\section{Kurikulum pada Program Studi IESP}

Kurikulum yang digunakan terdiri atas kurikulum Nasional dan kurikulum muatan lokal dengan mengakomodasi permintaan pengguna yaitu industri/instansi terkait. Jumlah SKS kurikulum S1 Jurusan IImu Ekonomi Studi Pembangunan adalah 144 160 SKS yang harus diselesaikan dalam 8 (delapan) semester. Kurikulum tersebut dijabarkan dari visi, misi, dan tujuan Program Studi untuk menghasilkan lulusan yang berkompeten, profesional, dan berdedikasi tinggi dalam bidang keilmuannya.

\section{Struktur dan Isi Kurikulum}

Struktur dan isi kurikulum Jurusan IImu Ekonomi Studi Pembangunan Reguler Sore yang digunakan mengacu pada standar kurikulum Nasional. Kurikulum tersebut mengelompokkan mata kuliah berdasarkan :

a. Mata kuliah Pengembangan Kepribadian (MPK) adalah kelompok mata kuliah yang bertujuan untuk mengembangkan manusia Indonesia yang beriman dan bertaqwa terhadap Tuhan Yang Maha Esa dan berbudi pekerti luhur, berkepribadian yang 
kuat, dan mandiri serta mempunyai rasa tanggung jawab kemasyarakatan dan kebangsaan.

b. Mata kuliah Keilmuan dan Keterampilan (MKK) adalah kelompok mata kuliah yang ditujukan terutama untuk memberikan landasan penguasaaan ilmu dan keterampilan tertentu.

c. Mata kuliah Keahlian Berkarya (MKB) adalah kelompok mata kuliah yang bertujuan menghasilkan tenaga ahli dengan kekayaan berdasarkan dasar ilmu dan ketrampilan yang dikuasai.

d. Mata kuliah Perilaku Berkarya (MPB) adalah kelompok mata kuliah yang bertujuan untuk membentuk sikap dan perilaku seseorang dalam berkarya, menurut tingkat keahlian berdasarkan dasar ilmu dan keterampilan yang dikuasai.

e. Mata kuliah

Berkehidupan Bermasyarakat (MBB) adalah kelompok mata kuliah yang diperlukan seseorang untuk dapat memahami kaidah berkehidupan bermasyarakat sesuai dengan pilihan keahlian dalam berkarya.

f. Kurikulum lokal dan mata kuliah pilihan

g. Kurikulum Jurusan IImu Ekonomi Studi Pembangunan cukup fleksibel dalam mengakomodasi perubahan standar terbaru dalam bidang IImu Ekonomi Studi Pembangunan. Demikian juga relevansi kurikulum terhadap kebutuhan lokal cukup akomodatif. Mata kuliah yang terkandung dalam struktur kurikulum Program Studi IImu Ekonomi Studi Pembangunan terdiri atas mata kuliah wajib dan mata kuliah pilihan. Di antara mata kuliah wajib mahasiswa juga diberikan kebebasan untuk memilih mata kuliah pilihan untuk bisa menyelesaikan studinya.

Tabel 1 Komposisi SKS batas minimal yang ditempuh untuk Lulusan S1 Program Studi Ilmu Ekonomi Studi Pembangunan

\begin{tabular}{|l|c|c|c|c|c|}
\hline Kelompok & Kurikulum Inti & \multicolumn{3}{|c|}{ Kurikulum Institusi } & \multirow{2}{*}{$\begin{array}{c}\text { Total } \\
\text { Mata Kuliah }\end{array}$} \\
\cline { 3 - 5 } WN & WL & WLK & PL & SKS \\
\hline \hline I. MPK & 10 & - & - & - & 10 \\
\hline II. MKK & 39 & 6 & - & - & 45 \\
\hline III. MKB & 17 & 12 & 3 & 3 & 35 \\
\hline IV. MPB & 15 & 18 & 6 & 3 & 42 \\
\hline V. MBB & 3 & 3 & 6 & - & 12 \\
\hline \hline Jumlah & 84 & 37 & 15 & 6 & 144 \\
\hline
\end{tabular}

\section{Kebutuhan Dunia Kerja}

Memasuki abad ke 21 yang ditandai oleh libelarisasi perdagangan diperlukan upaya sungguh-sungguh untuk meningkatkan kualitas sumber daya manusia (SDM) yang benar-benar siap menghadapi persaingan global yang makin terbuka. Permasalahan yang dihadapi lulusan PTN maupun PTS (SDM) di Indonesia adalah ketidaksiapan saat akan memasuki dunia kerja. Hal ini 
menjadi tantangan bagi dunia pendidikan di Indonesia agar mampu menciptakan tenaga kerja yang profesional sehingga SDM Negara Indonesia mampu bersaing dengan SDM negara lain seperti Malaysia, Singapura, dan Filipina. Oleh karena itu, tuntutan untuk berani melakukan inovasi dan bekerja sungguh-sungguh untuk mempersiapkan sumber daya manusia masa depan yang sudah terdidik untuk bersaing dalam dunia kerja harus ditindaklanjuti. SDM yang diinginkan di era globalisasi ini tidak hanya sebagai pekerja, tetapi juga sebagai wirausahawan (entrepreneurs). Sejalan dengan kebijakan pemerintah dalam hal ini Departemen Pendidikan Nasional, maka proses pendidikan di perguruan tinggi harus memperhatikan lingkungan dan tuntutan kebutuhan dunia kerja, khususnya dunia usaha dan dunia industri, terhadap SDM yang profesional.

Dunia kerja pada masa mendatang akan menjaring secara selektif calon tenaga kerja yang benar-benar profesional pada bidangnya, oleh karena itu salah satu tantangan utama bagi lulusan perguruan tinggi adalah mempersiapkan diri sebaikbaiknya sebelum memasuki dunia kerja. Upaya peningkatan SDM khususnya dalam pendidikan tinggi adalah melalui program Co-Op (Co-Operative Education), RAPID
(Riset Andalan Perguruan Tinggi dan Industri) dan program riset unggulan lainya yang merupakan sarana penting bagi pengembangan diri dan kemampuan berwirausaha serta kemandirian secara profesional bagi lulusannya. Untuk menghadapi tuntutan tersebut, Direktur Jenderal Pendidikan Tinggi telah menyatakan bahwa salah satu tujuan utama di bidang Pendidikan Tinggi untuk Pelita VI dan menyongsong tonggaktonggak waktu tahun 2005 dan 2020 adalah; "Penataan Sistem Pendidikan Tinggi agar Lebih Sesuai dengan Kebutuhan Masyarakat dan Pembangunan."

\section{Profil Jurusan Ilmu Ekonomi dan Studi Pembangunan (IESP) FEB Unram}

Program Studi IESP Reguler Sore Fakultas Ekonomi dan Bisnis Universitas Mataram didirikan sebagai upaya merespon tuntutan kebutuhan akan sumber daya manusia berpendidikan tinggi yang bermutu dan berintegritas. Kebutuhan tersebut semakin terasa sejalan dengan dinamika pembangunan bangsa dan situasi global saat ini yang menuntut kapasitas sumber daya manusia yang semakin tinggi. Mobilitas sumber daya manusia dan keterbukaan pasar kerja menumbuhkan iklim kompetisi yang semakin ketat sehingga setiap orang dituntut untuk memiliki kompetensi yang dibutuhkan. 
Program Studi IESP memiliki tanggung jawab akademis yang besar guna menyediakan sumber daya manusia terdidik yang berkualitas dan mempunyai daya saing yang tinggi. Kesadaran akan tanggung jawab tersebut menyebabkan Program Studi IESP terus berupaya meningkatkan kualitas proses pembelajaran, pelayanan kepada mahasiswa, kualitas dan kualifikasi dosen, peninjauan kurikulum dan silabus secara berkala. Melalui usaha dan kerja keras tersebut diharapkan Program Studi IESP dapat menghasilkan lulusan yang bermutu dan berdaya saing serta menjunjung tinggi budaya akademik seperti kejujuran, disiplin, terbuka dan menghargai pendapat orang lain.

\section{Visi Program Studi IESP}

Visi Program Studi IESP adalahTerwujudnya Program Studi Ekonomi Pembangunan yang Bermutu dan Berstandar Nasional maupun global. Untuk mewujukdan visi tersebut maka orientasi pendidikan akademis yang tercermin dari kurikulum, proses dan metode pembelajaran diarahkan untuk mencapai visi tersebut. Visi ini akan dapat diwujudkan dengan tersedianya sumber daya dan fasilitas yang dimiliki Program Studi. Program Studi IESP didukung oleh staf pengajar yang sebagian besar berasal dari Fakultas Ekonomi dan Bisnis Universitas Mataram. Sebagian besar tenaga pengajar memiliki kompetensi di bidangnya masing-masing yang memiliki kualifikasi Magister, Doktor dan Guru Besar

\section{Misi Program Studi IESP}

Sejalan dengan Visi di atas dan juga Tridharma Perguruan Tinggi, Misi Program Studi IESP Fakultas Ekonomi dan Bisnis Universitas Mataram adalah:

a. Menyelenggarakan pendidikan yang berkualitas untuk menghasilkan lulusan yang unggul dalam bidang IImu Ekonomi dan Studi Pembangunan sehingga mampu bersaing di pasar kerja, dan/atau siap menciptakan peluang kerja baru sebagai enterpreneur.

b. Menyelenggarakan penelitian yang berorientasi pada pengembangan bidang IImu Ekonomi dan Studi Pembangunan dengan memanfaatkan berbagai sumber pendanaan baik bersifat regional, nasional maupun internasional

c. Menyelenggarakan Pengabdian pada Masyarakat untuk memberikan kontribusi dalam upaya transformasi masyarakat.

d. Mengembangkan potensi sumberdaya manusia, sumberdaya material dan 
nonmaterial lainnya yang dimiliki secara optimal

e. Menyelenggarakan

kerjasama kemitraan dengan berbagai pihak/lembaga dalam rangka pengembangan institusi dan menunjang pembangunan.

\section{Tujuan Program Studi IESP}

a. Menghasilkan lulusan yang berkualitas sehingga mampu bersaing dalam pasar kerja dan/atau menciptakan lapangan kerja baru sebagai enterpreneur.

b. Menghasilkan kajian dan penelitian yang berkualitas sehingga dapat dipublikasikan pada berbagai jurnal ilmiah berskala nasional dan internasional.

c. Mendesiminasi hasil penelitian dan kajian akademis melalui pengabdian pada masyarakat dalam upaya transformasi masyarakat.

d. Mewujudkan dan mengorganisasikan sumberdaya manusia yang berdaya saing dan mampu berkompetisi dalam bidang pendidikan, penelitian dan pengabdian pada masyarakat.

e. Mengorganisasikan sumberdaya material dan non material yang produktif dan dapat memberikan kontribusi untuk mendukung pengembangan Program Studi secara optimal, melalui penguatan teknologi dan informasi.

f. Mewujudkan kerjasama/kemitraan dengan berbagai pihak (mitra) di berbagai level baik regional, nasional dan internasional.

\section{Sasaran Program Studi}

Untuk mendukung Visi dan Misi telah dikembangkan sejumlah sasaran Program Studi sebagai berikut:

a. Mendapatkan akreditasi A dari Badan Akreditasi Nasional Perguruan Tinggi (BAN-PT)

b. Meningkatnya jumlah penelitian dan pengabdian yang didanai oleh berbagai pihak baik untuk level regional, nasional maupun internasional.

c. Meningkatnya jumlah publikasi ilmiah pada berbagai jurnal ilmiah nasional maupun internasional yang dapat dijadikan referensi bagi para peneliti

d. Meningkatnya jumlah produk intelektual yang unggul dan bermanfaat untuk meningkatkan kesejahteraan masyarakat.

Untuk mencapai sasaran-sasaran tersebut dikembangkan berbagai strategi antara lain:

a. Meningkatkan kerjasama kemitraan dengan pihak ketiga di berbagai level baik regional, nasional dan 
|52 Akung Daeng, Ihsan Rois, Ade Paranata/Analisis Penelusuran Alumni ...

internasional dalam bidang bulan. Adapun lainnya merupakan masa pendidikan, penelitian dan pengabdian

b. Meningkatkan publikasi hasil penelitian dan kajian terkait dengan bidang yang menjadi prioritas pengembangan Program Studi di berbagai jurnal ilmiah baik tingkat nasional maupun internasional.

c. Menyelenggarakan pertemuanpertemuan ilmiah tingkat nasional dan internasional terkait dengan bidang yang menjadi prioritas pengembangan Program Studi bekerjasama dengan berbagai pihak.

d. Mengembangkan institusi dialog dalam upaya pengembangan sumberdaya non material.

\section{Profil Lulusan Jurusan IESP}

Profil lulusan menggambarkan kompetensi Iulusan Jurusan IESP. Profil Iulusan ini meliputi tiga hal yang yaitu masa tunggu lulusan, persentase lulusan yang sudah bekerja, dan penghasilan pertama yang diperoleh. Data ini sangat diperlukan untuk isian boring akreditasi. Masa tunggu lulusan Jurusan IESP merupakan lama waktu menunggu sampal mendapatkan pekerjaan yang pertama kali sesudah lulus sarjana yaitu dihitung setelah yudisium. Rentang waktu masa tunggu lulusan dikelompokkan menjadi < 8 bulan, 8-16 bulan, 17-24 bulan, 25-32 bulan, dan $>32$ tunggu lulusan dari Jurusan IESP yang lebih dari satu tahun, tetapi awalnya berkehendak untuk tidak bekerja (seperti; memilih menjadi ibu rumah tangga karena keuangan keluarga sudah dijamin suami, melanjutkan studi lanjut, atau ada larangan). Persentase lulusan yang sudah bekerja merupakan jumlah lulusan Jurusan IESP dari tahun penelitian yang sudah bekerja dibandingkan jumlah lulusan pada tahun penelitian. Penghitungan persentase lulusan yang sudah bekerja ini dihitung berdasarkan data yang diperoleh. Penghasilan pertama yang diperoleh lulusan Jurusan IESP dalam pekerjaan pertamanya.

\section{Tracer Studi}

Seberapa besar lulusan perguruan tinggi mampu berkiprah dalam Pembangunan sesuai relevansi pendidikannya dapat dilakukan upaya penelusuran terhadap lulusannya (Tracer Study). Tracer Study merupakan pendekatan yang memungkinkan institusi pendidikan tinggi memperoleh informasi tentang kekurangan yang mungkin terjadi dalam proses pendidikan dan proses pembelajaran dan dapat merupakan dasar untuk perencanaan aktivitas untuk penyempurnaan di masa mendatang. Hasil Tracer Study dapat digunakan perguruan 
tinggi untuk mengetahui keberhasilan proses pendidikan yang telah dilakukan terhadap anak didiknya. Bahkan dalam program hibah kompetisi maupun akreditasi selalu mempersyaratkan adanya data hasil Tracer Study tersebut melalui parameter masa tunggu lulusan, persen lulusan yang sudah bekerja, dan penghasilan pertama yang diperoleh.

Harald Schomburg (2003: 11) mendefiniskan Tracer Study merupakan pendekatan yang memungkinkan institusi pendidikan tinggi memperoleh informasi tentang kekurangan yang mungkin terjadi dalam proses pendidikan dan proses pembelajaran dan dapat merupakan dasar untuk perencanaan aktivitas untuk penyempurnaan di masa mendatang. Informasi yang diberikan oleh lulusan yang berhasil di profesinya diperlukan misalnya informasi tentang pengetahuan dan penampilan yang relevan (hubungan antara pengetahuan terhadap ketrampilan dan tuntutan pekerjaan, area pekerjaan, posisi profesi). Selain itu, para lulusan dapat juga diminta untuk menilai kondisi studi yang mereka alami selama mengikuti proses pendidikan dan pembelajaran. Tracer Study dapat juga digunakan sebagai kegiatan mencari informasi tentang kebutuhan stakeholder tehadap alumni. Tujuan dari kegiatan ini adalah mengumpulkan informasi dan masukan yang relevan dari lulusan terkait dengan "learning dan working experience" yang dialami oleh lulusan guna pengembangan perguruan tinggi. Menurut Schomburg (2003) tujuan utama dari kegiatan Tracer Study adalah untuk mengetahui/ mengidentifikasi kualitas lulusan di dunia kerja, sedangkan tujuan khusus Tracer Study adalah : (1) Mengidentifikasi profil kompetensi dan keterampilan lulusan; (2) Mengetahui relevansi dari pelaksanaan kurikulum yang telah diterapkan di perguruan tinggi dengan kebutuhan pasar tenaga kerja dan pengembangan profesional di dalam kompetensi jurusan; (3) Untuk mengevaluasi hubungan dari kurikulum dan studi di jurusan sebagai pengembangan keilmuan; (4) Sebagai kontribusi dalam proses akreditasi jurusan.Penelusuran lulusan (Tracer Study) adalah salah satu hal strategis yang harus dilakukan oleh setiap institusi pendidikan. Setidaknya ada tiga manfaat yang bisa diperoleh dari pelaksanaan kegiatan ini, yaitu: (1) Mengetahui stakeholder satisfaction, dalam hal ini lulusan, terkait dengan learning experiences yang mereka alami, untuk dijadikan alat eveluator kinerja institusi; (2) Mendapatkan masukan yang relevan sebagai dasar pijakan pengembangan institusi, terkait 
dengan kemampuan bersaing, kualitas, dan working experiences lulusan yang bisa digunakan untuk menangkap kesempatan dan menanggulangi ancaman ke depan; (3) Meningkatkan hubungan lulusan dan almamater, karena apabila dilihat dari pengalaman institusi-institusi pendidikan terkenal, ikatan lulusan dan almamater yang kuat akan banyak membawa banyak manfaat kepada almamater seiring dengan diakuinya kiprah lulusan di masyarakat.

\section{METODE PENELITIAN}

\section{Jenis Penelitian}

Jenis penelitian yang digunakan dalam penelitian ini adalah penelitian deskriptif evaluatif yaitu penelitian yang berusaha mendeskripsikan profil lulusan dan relevansi konsentrasi pada kurikulum di Jurusan IESP melalui pendekatan survei Penentuan lokasi penelitian dilakukan secara purposive sampling yaitu menentukan lokasi penelitian secara sengaja, lokasi penelitian adalah 5 kabupaten/kota di pulau Lombok

\section{Jenis Data}

Jenis data dalam penelitian ini adalah :

a. Data kuantitatif yaitu data yang diperlukan dalam penelitian berupa angka-angka yang dapat diukur besarnya dan dapat dihitung secara pasti seperti data jumlah alumni program studi ekonomi pembangunan fakultas ekonomi universitas mataramselama 5 tahun terakhir dari tahun 2014-2019

b. Data kualitatif yaitu data yang diperlukan dalam penelitian ini berupa keterangan dan kebijakan yang berkaitan dengan pengembangan program studi ekonomi pembangunan fakultas ekonomi dan bisnis universitas mataram

\section{Sumber Data}

Data primer adalah data yang diperoleh secara langsung dari alumni yang dapat memberikan informasi atau keterangan yang diperlukan untuk kebutuhan penelitian. Data primer diperoleh dari kuesioner/daftar pertanyaan yang dibagikan kepada alumni jurusan IESP.

\section{Teknik dan alat pengumpul data}

Teknik yang digunakan dalam mengumpulkan data dalam penelitian ini adalah sebagai berikut:

a. Dokumentasi, yaitu pengumpulan data berupa catatan-catatan yang tersedia pada jurusan IESP

b. Wawancara,yaitu teknik pengumpulan data dengan cara tanya jawab langsung dengan responden dengan menggunakan kuesioner/angketyang dibagikan kepada alumni jurusan IESP

\section{Variabel Penelitian}


1. Masa Tunggu Mendapatkan Pekerjaan Pertama

2. Lama kuliah alumni IESP

3. Pekerjaan pertama alumni

4. Pendapatan pertama alumni

5. Tanggapan pengguna alumni IESP

6. Keahlian alumni IESP di dunia kerja

Metode Pengumpulan Data

Metode pengumpulan data yang digunakan dalam penelitian ini adalah Metode pengambilan sampel yang digunakan dalam penelitian ini adalah nonprobability sampling dimana pengambilan sampel didasarkan pada pertimbangan subjek peneliti yaitu karena pertimbangan biaya, lokasi, waktu dan informasi yang dibutuhkan oleh peneliti. Metode nonprobability sampling yang digunakan adalah teknik accidental sampling, teknik penentuan sampel berdasarkan kebetulan, yaitu siapa yang kebetulan bertemu dengan peneliti dapat dijadikan sampel jika dipandang sesuai. Total sampel yang digunakan dalam penelitian ini adalah 100 orang responden (alumni)

\section{Teknik Analisis Data}

Teknik analisis data yang digunakan adalah analisis deskriptif dengan pendekatan kuantitatif untuk melihat gambaran dari Iulusan (alumni) jurusan Ilmu Ekonomi dan
Studi Pembangunan Fakultas Ekonomi dan Bisnis Universitas Mataram.

\section{HASIL DAN PEMBAHASAN}

\section{Lama Alumni IESP dalam Menempuh Studi di Jurusan IESP Fakultas Ekonomi UNRAM}

Alumni jurusan IESP menempuh kuliah di jurusan IESP FE-UNRAM dari tahun 2014 sampai dengan tahun 2019 dengan menggunakan 50 responden alumni yang dijadikan sebagai sampel dibagi menjadi 7 kategori lama kuliah menjadi 3 tahun, 3,6 tahun, 4 tahun, 4,5 tahun, 5 tahun, 6,5 tahu dan 7,5 yang terlihat pada grafik 4.1 di bawah ini.

\section{Grafik 1 Lama Menempuh Studi Alumni} IESP

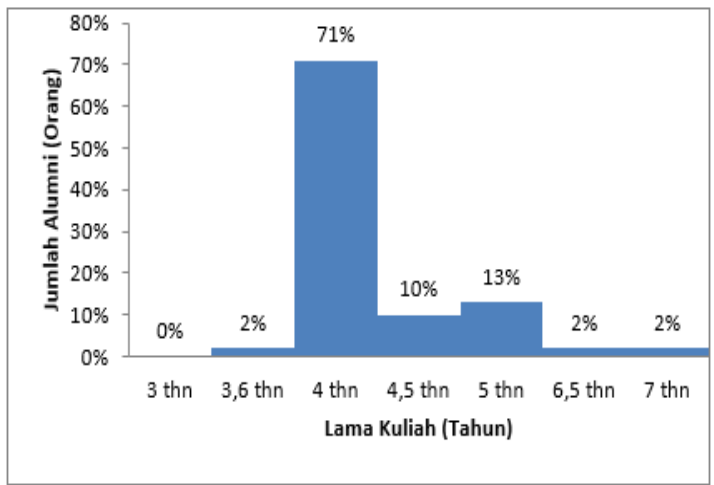

Sumber: data primer (diolah)

Dari grafik 1 diatas terlihat bahwa dengan menggunakan 50 alumni yang dijadikan responden dari lulusan tahun 2014-2019 sebagian besar alumni IESP menumpuh masa studi dalam jangka waktu 4 tahun sebanyak $71 \%$ orang alumni, hal ini berarti masa studi mahasiswa di jurusan IESP 
sebagian besar tepat pada waktu dan menjadi keberhasilan bagi program studi dalam mengelola jurusan IESP, sedangkan sisanya alumni yang di jadikan responden dalam penelitian ini terdapat alumni yang lulus dengan sangat cepat yaitu 3 tahun 6 bulan dengan jumlah $2 \%$, hal ini menunjukkan suatu prestasi bagi jurusan IESP karena meluluskan alumninya kurang dari 4 tahun.

\section{Masa Tunggu Alumni IESP Mendapatkan Pekerjaan}

Alumni jurusan IESP memiliki Masa tunggu untuk mendapatkan pekerjaan terlihat pada grafik 4.2 dibawah ini, dimana masa tunggu alumni mendapatkan pekerjaan dibagi menjadi 4 kategori yaitu, masa tunggu $<6$ bulan, masa tunggu $6-12$ bulan, masa tunggu 12-18 bulan, dan masa tunggu diatas (>) 18 bulan.

\section{Grafik 2 Masa Tunggu Alumni IESP Mendapatkan Pekerjaan}

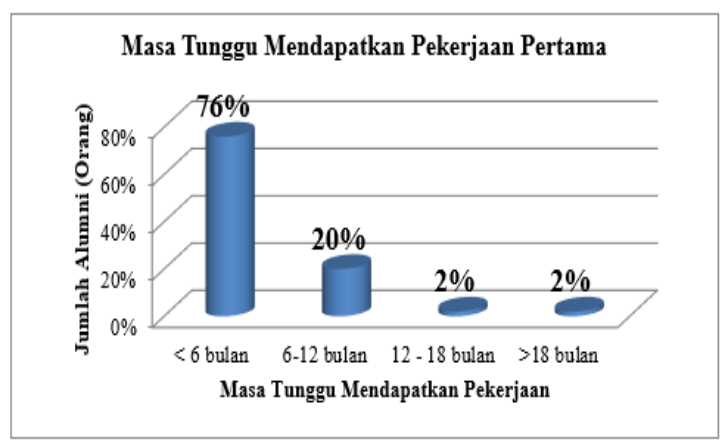

Sumber: data primer (diolah)

Dari grafik 2 diatas terlihat bahwa dengan menggunakan 50 responden alumni terdapat rentang masa tunggu alumni IESP untuk mendapatkan pekerjaan relatif singkat yaitu kurang dari 6 bulan sebanyak $76 \%$ alumni, hal ini berarti alumni IESP sangat cepat terserap di dunia kerja baik yang bekerja di instansi pemerintahan, swasta, maupun sebagai berwirausaha, sedangkan alumni yang memiliki masa tunggu paling lama satu tahun atau 6-12 bulan sebanyak $20 \%$ alumni. Terdapat masing-masing $2 \%$ alumni yang memiliki masa tunggu diatas satu tahun atau 12-18 bulan dan $>18$ bulan artinya alumni IESP sangat cepat terserap dunia kerja.

\section{Pekerjaan Pertama Alumni}

Dari 50 responden yang digunakan dalam studi penelusuran ini Pekerjaan pertama alumni dibagi menjadi 5 kategori pekerjaan yaitu pegawai Swasta, Wiraswasta, Pegawai BUMN, PNS, dan Honorer

\section{Grafik 3 Pekerjaan Pertama Alumni IESP}

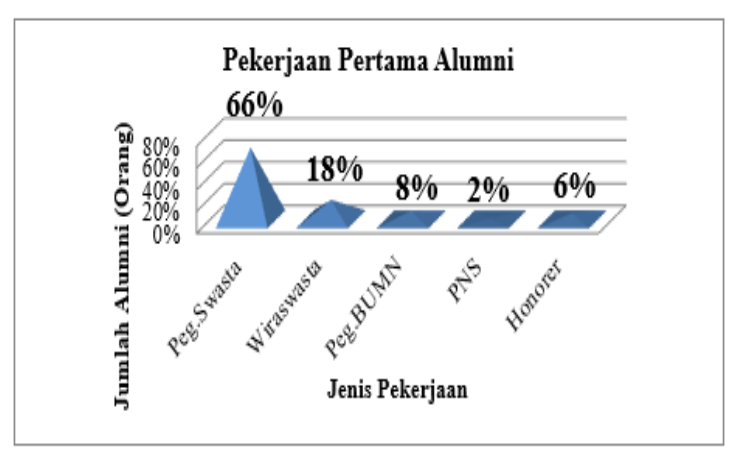

Sumber: data primer (diolah)

Dari grafik 3 diatas terlihat bahwa Pekerjaan pertama alumni IESP sebagian besar adalah pegawai swasta dengan jumlah 66\%, pekerjaan pertama alumni IESP sebagian besar berada pada sektor 
swasta atau perusahaan swasta meskipun ada juga alumni IESP yang bekerja di sector pemerintahan seperti menjadi pegawai di perusahaan BUMN dengan jumlah responden sebanyak $8 \%$, sebagai pegawai negeri sipil (PNS) dengan jumlah responden sebanyak $2 \%$. Untuk alumni yang dijadikan responden yang bekerja atau menjadi wiraswasta dengan jumlah $18 \%$, hal ini berarti alumni IESP tidak harus bekerja di sector pemerintahan atau di BUMN tetapi peluang juga cukup besar disektor wiraswasta karena di dalam jurusan IESP juga terdapat mata kuliah kewirausahaan, selain itu juga alumni IESP yang menjadi pegawai honorer sebanyak $6 \%$.

\section{Penghasilan Pertama Alumni IESP}

Penghasilan pertama alumni yang dijadikan responden dalam penelitian ini dibagi menjadi 5 kategori penghasilan yaitu penghasilan pertama responden kurang dari 1 juta, penghasilan pertama responden diantara $\mathrm{Rp} 1.000 .000$ - Rp 1.500.000, penghasilan pertama responden diantara $\mathrm{Rp} 1.500 .000$ - Rp 2.000.000, penghasilan pertama responden diantara $\mathrm{Rp} 2.000 .000$ - Rp 2.500.000 dan penghasilan pertama responden lebih dari (>) $\mathrm{Rp}$ 2.500.000. Gambaran penghasilan pertama alumni yang dijadikan responden terlihat pada grafik 4.4 dibawah ini

\section{Grafik 4 Besarnya Penghasilan Pertama} Alumni IESP

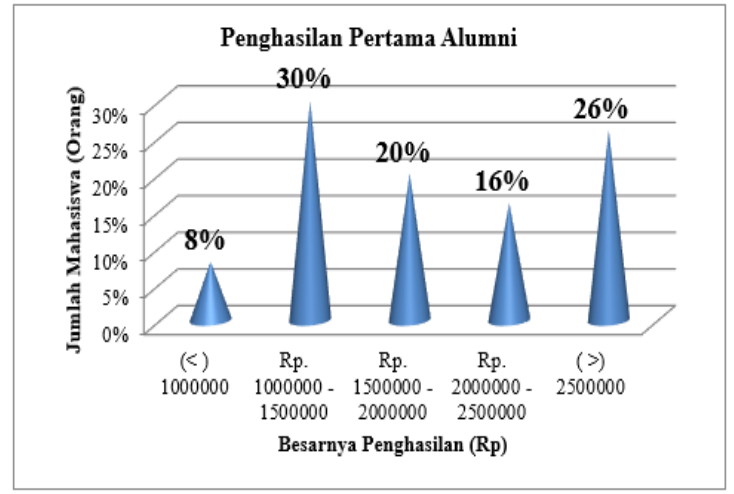

Sumber: data primer (diolah)

Dari grafik 4 diatas terlihat bahwa dari 50 alumni yang dijadikan responden sebagian besar alumni memiliki penghasilan pertama kurang dari 1 juta yaitu sebanyak $8 \%$ dan penghasilan alumni pertama yang berada pada kisaran 1 juta sampai dengan 1,5 juta berjumlah $30 \%$, hal ini berarti bahwa penghasilan pertama alumni kurang dari satu juta sangat sedikit jumlahnya, artinya alumni IESP sebagian besar sudah dapat menikmati gaji yang baik atau pendapatan yang layak dan alumni yang mendapat gaji dibawah satu juta tersebut biasanya alumni yang masih menjadi pegawai kontrak atau honorer yang sangat sedikit jumlahnya, dimana dikarenakan alumni hanya menjadikan pekerjaan dengan gaji yang kecil sebagai batu loncatan untuk mendapatkan pengalaman kerja yang sangat dibutuhkan 
untuk menuju pekerjaan yang lebih baik dengan pendapatan yang lebih tinggi.

Alumni yang dijadikan responden dengan penghasilan pertama diantara 1,5 -2 juta sebanyak 20\%, penghasilan pertama 2 juta-2,5 juta sebanyak $16 \%$ sedangkan penghasilan pertama alumni diatas 2,5 juta sebanyak 26\%, hal ini berarti Alumni IESP sebagian besar telah menikmati gaji yang tinggi dengan memiliki tempat kerja yang bagus dan menjanjikan penghasilan yang tinggi.

\section{Relevansi Evaluasi kinerja lulusan oleh} pihak pengguna pada jurusan IESP FEB

\section{Universitas Mataram}

Integritas Lulusan (Alumni) IESP bisa dilihat pada hrafik di bawah ini

\section{Grafik 5 Integritas Lulusan (Alumni) IESP}

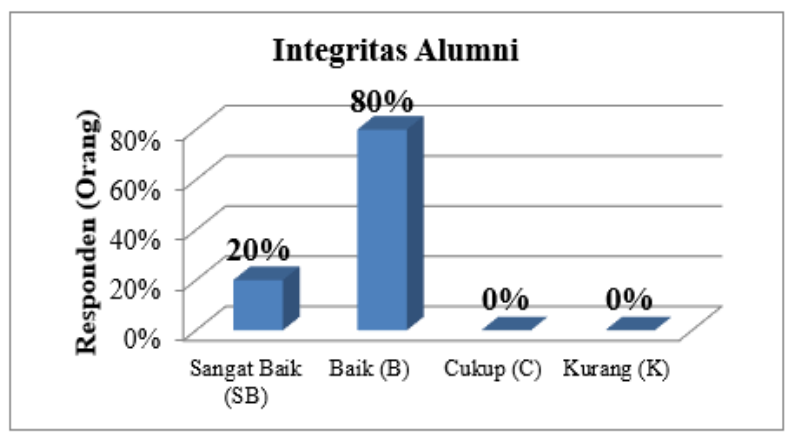

Sumber: data primer (diolah)

Pada Grafik 5 terlihat bahwa tanggapan pengguna terhadap integritas alumni IESP memiliki penilaian sebanyak $20 \%$ alumni IESP memiliki integritas yang sangat baik (SB), tanggapan pengguna terhadap integritas alumni IESP memiliki penilaian sebanyak $80 \%$ alumni IESP memiliki integritas yang baik (B). Sedangkan tanggapan pengguna alumni IESP memiliki penilaian Integritas alumni IESP dengan nilai Cukup (C) tidak ada.

\section{Profesionalisme Lulusan (Alumni) IESP Grafik 6 Profesionalisme Lulusan} (Alumni) IESP

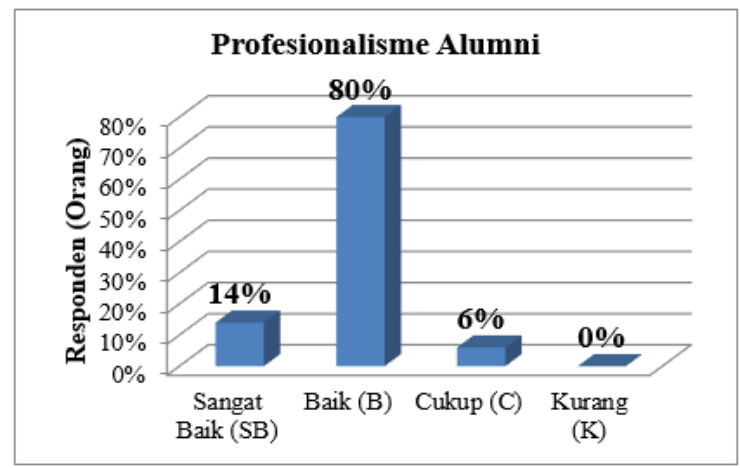

Sumber: data primer (diolah)

Pada Grafik 6 terlihat bahwa tanggapan pengguna terhadap Profesionalisme alumni IESP memiliki penilaian sebanyak $14 \%$ alumni IESP memiliki integritas yang sangat baik (SB), tanggapan pengguna terhadap Profesionalisme alumni IESP memiliki penilaian sebanyak $80 \%$ alumni IESP memiliki integritas yang baik (B). Sedangkan tanggapan pengguna alumni terhadap Profesionalisme alumni yang memberikan nilai Cukup (C) sebanyak 6\%

Bahasa Inggris Lulusan (Alumni) IESP Grafik 7 Bahasa Inggris Lulusan (Alumni) IESP

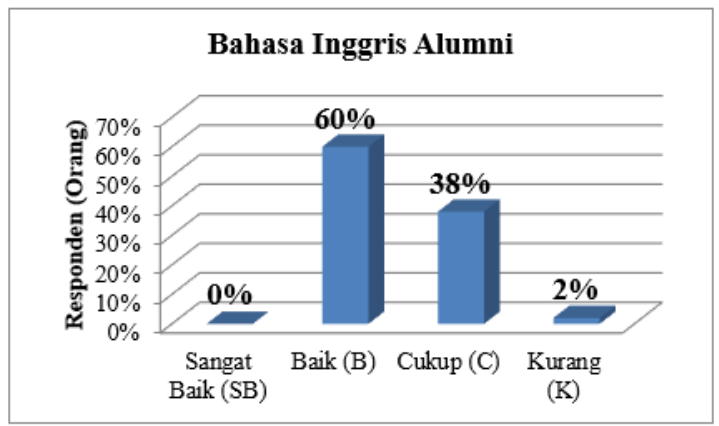


Pada Grafik 7 terlihat bahwa tanggapan pengguna terhadap Bahasa Inggris alumni IESP memiliki penilaian sebanyak $60 \%$ alumni IESP memiliki integritas yang baik (B). Sedangkan tanggapan pengguna alumni terhadap keahlian bahasa inggris alumni memberikan nilai Cukup (C) sebanyak $38 \%$ alumni, sedangkan pengguna alumni IESP memberikan penilaian kurang (K) terhadap keahlian bahasa inggris alumni sebanyak $2 \%$ saja. Hal ini berarti bahwa pengguna alumni kurang puas dengan keahlian bahasa inggris alumni IESP, dimana pengguna alumni IESP tidak ada yang memberikan penilaian sangat bagus (SB) terhadap bahasa inggris alumni.

Keahlian Komputer (IT) Lulusan (Alumni) IESP

\section{Grafik 8 Keahlian Komputer (IT) Alumni IESP}

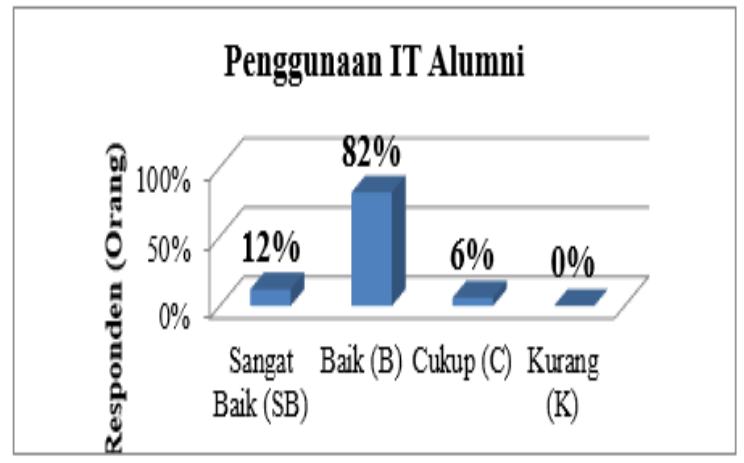

\section{Sumber: data primer (diolah)}

Pada Grafik 8 terlihat bahwa tanggapan pengguna terhadap keahlian IT alumni IESP memiliki penilaian sebanyak $12 \%$ alumni IESP memiliki keahlian IT yang sangat baik
(SB), tanggapan pengguna terhadap keahlian IT alumni IESP memiliki penilaian sebanyak $82 \%$ alumni IESP memiliki keahlian IT yang baik (B). Sedangkan tanggapan pengguna alumni terhadap keahlian IT alumni yang memberikan nilai Cukup (C) sebanyak $6 \%$ alumni, sedangkan tidak ada pengguna alumni IESP yang memberikan penilaian kurang $(\mathrm{K})$ terhadap keahlian IT alumni. Hal ini berarti bahwa rata-rata alumni IESP memiliki kemampuan IT yang cukup baik.

\section{Komunikasi Lulusan (Alumni) IESP}

Grafik 9 Komunikasi Alumni IESP

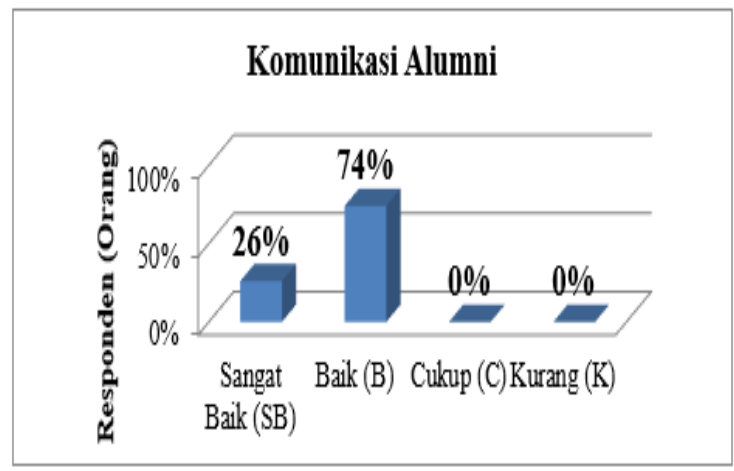

Sumber: data primer (diolah)

Pada Grafik 9 terlihat bahwa tanggapan pengguna terhadap Komunikasi alumni IESP memiliki penilaian sebanyak $26 \%$ alumni IESP memiliki Komunikasi yang sangat baik (SB), tanggapan pengguna terhadap Komunikasi alumni IESP memiliki penilaian sebanyak $74 \%$ alumni IESP memiliki Komunikasi yang baik (B). Sedangkan tanggapan pengguna alumni terhadap Komunikasi alumni yang 
memberikan nilai Cukup (C) dan kurang (K) terhadap Komunikasi alumni tidak ada. Hal ini berarti bahwa rata-rata alumni IESP memiliki kemampuan IT yang cukup baik, dimana berarti bahwa komunikasi alumni IESP didunia kerja cukup komunikatif dalam pekerjaannya sehari-hari.

\section{Kerjasama Tim Lulusan (Alumni) IESP}

\section{Grafik 10 Kerjasama Tim Alumni IESP}

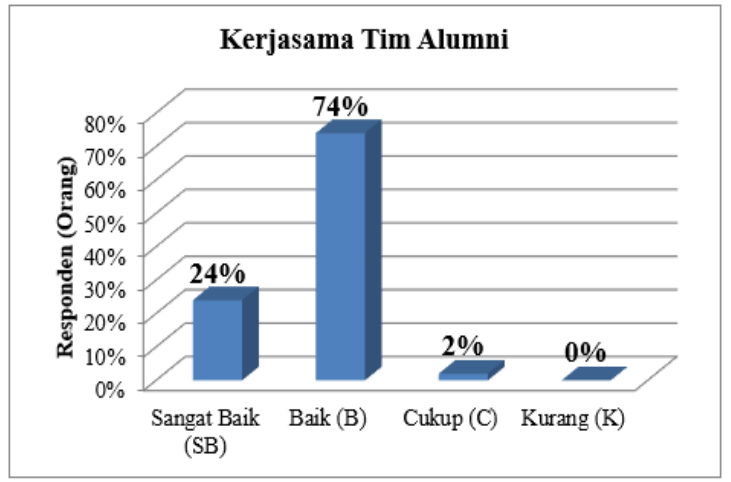

Sumber: data primer (diolah)

Pada Grafik 10 terlihat bahwa tanggapan pengguna terhadap Kerjasama Tim alumni IESP memiliki penilaian sebanyak $24 \%$ alumni IESP memiliki Kerjasama Tim yang sangat baik (SB), tanggapan pengguna terhadap Kerjasama Tim alumni IESP memiliki penilaian sebanyak $74 \%$ alumni IESP memiliki Kerjasama Tim yang baik (B). Sedangkan tanggapan pengguna alumni terhadap Kerjasama Tim alumni yang memberikan nilai Cukup (C) sebanyak 2\% alumni, sedangkan tidak ada pengguna alumni IESP yang memberikan penilaian kurang (K) terhadap Kerjasama Tim. Hal ini berarti bahwa alumni IESP memiliki
Kerjasama Tim yang cukup baik dan dapat bekerja dengan siapapun di lingkungan kerja.

\section{Pengembangan Diri Lulusan (Alumni) IESP Grafik 11 Pengembangan Diri Alumni IESP}

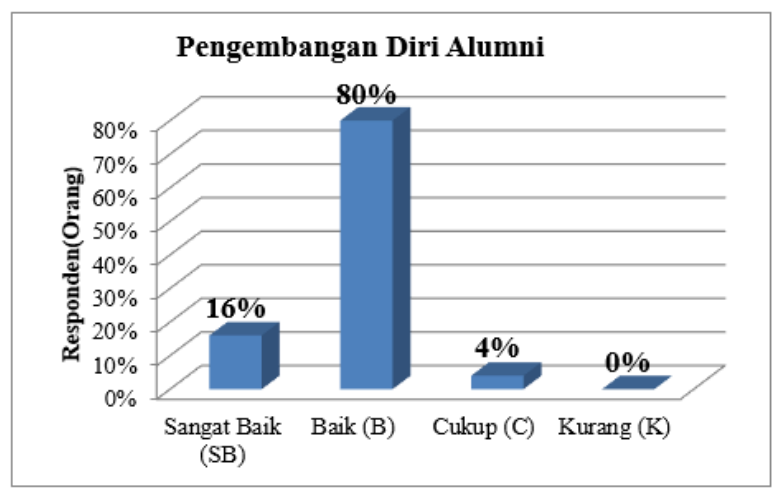

Sumber: data primer (diolah)

Pada Grafik 11 terlihat bahwa tanggapan pengguna terhadap Pengembangan Diri alumni IESP memiliki penilaian sebanyak 16\% alumni IESP memiliki Pengembangan Diri yang sangat baik (SB), tanggapan pengguna terhadap Pengembangan Diri alumni IESP memiliki penilaian sebanyak 80\% alumni IESP memiliki Pengembangan Diri yang baik (B). Sedangkan tanggapan pengguna alumni terhadap Pengembangan Diri alumni yang memberikan nilai Cukup (C) sebanyak 4\% orang alumni, sedangkan tidak ada pengguna alumni IESP yang memberikan penilaian kurang (K) terhadap Pengembangan Diri. Hal ini berarti bahwa alumni IESP memiliki Pengembangan Diri yang cukup baik, terutama dalam 
pengembangan diri, keahlian dan manajerial.

\section{Pembahasan}

Dari analisis data dalam penelitian ini terlihat bahwa alumni IESP menumpuh masa studi dalam jangka waktu 4 tahun sebanyak $71 \%$ alumni, hal ini berarti masa studi mahasiswa di jurusan IESP sebagian besar tepat pada waktu dan menjadi keberhasilan bagi program studi dalam mengelola jurusan IESP.

Untuk masa tunggu alumni IESP untuk mendapatkan pekerjaan relatif singkat yaitu kurang dari 6 bulan sebanyak 76\% alumni, hal ini berarti alumni IESP sangat cepat terserap di dunia kerja baik yang bekerja di instansi pemerintahan, swasta, maupun sebagai berwirausaha.

Pekerjaan pertama alumni IESP sebagian besar adalah pegawai swasta dengan jumlah 66\% alumni, pekerjaan pertama alumni IESP sebagian besar berada pada sektor swasta atau perusahaan swasta meskipun ada juga alumni IESP yang bekerja di sector pemerintahan seperti menjadi pegawai di perusahaan BUMN dengan jumlah $8 \%$, sebagai pegawai negeri sipil (PNS) dengan jumlah 2\% saja. Untuk alumni yang dijadikan responden yang bekerja atau menjadi wiraswasta dengan jumlah 18\%, hal ini berarti alumni IESP tidak harus bekerja di sector pemerintahan atau di BUMN tetapi peluang juga cukup besar disektor wiraswasta karena di dalam jurusan IESP juga terdapat mata kuliah kewirausahaan.

Penghasilan pertama alumni IESP kurang dari 1 juta yaitu sebanyak $8 \%$ dan penghasilan alumni pertama yang berada pada kisaran 1 juta sampai dengan 1,5 juta berjumlah 30\%, hal ini berarti bahwa penghasilan pertama alumni kurang dari satu juta sangat sedikit jumlahnya, artinya alumni IESP sebagian besar sudah dapat menikmati gaji yang baik atau pendapatan yang layak dan alumni yang mendapat gaji dibawah satu juta tersebut biasanya alumni yang masih menjadi pegawai kontrak atau honorer yang sangat sedikit jumlahnya, dimana dikarenakan alumni hanya menjadikan pekerjaan dengan gaji yang kecil sebagai batu loncatan untuk mendapatkan pengalaman kerja yang sangat dibutuhkan untuk menuju pekerjaan yang lebih baik dengan pendapatan yang lebih tinggi.

Tanggapan pengguna terhadap integritas alumni IESP memiliki penilaian sebanyak $20 \%$ alumni IESP memiliki integritas yang sangat baik (SB), tanggapan pengguna terhadap integritas alumni IESP memiliki penilaian sebanyak $80 \%$ alumni IESP memiliki integritas yang baik (B). Sedangkan tanggapan pengguna alumni 
IESP memiliki penilaian Integritas alumni IESP dengan nilai Cukup (C) dan Kurang (K) tidak ada.

Tanggapan pengguna terhadap Profesionalisme alumni IESP memiliki penilaian sebanyak $14 \%$ alumni IESP memiliki profsionalitas yang sangat baik (SB), tanggapan pengguna terhadap Profesionalisme alumni IESP memiliki penilaian sebanyak $80 \%$ alumni IESP memiliki profesionalisme yang baik (B). Sedangkan tanggapan pengguna alumni terhadap Profesionalisme alumni yang memberikan nilai Cukup (C) sebanyak 6\% alumni.

Tanggapan pengguna terhadap Bahasa Inggris alumni IESP memiliki penilaian sebanyak $60 \%$ alumni IESP memiliki bahasa inggris yang baik (B). Sedangkan tanggapan pengguna alumni terhadap keahlian bahasa inggris alumni memberikan nilai Cukup (C) sebanyak 38\% alumni, sedangkan pengguna alumni IESP memberikan penilaian kurang $(\mathrm{K})$ terhadap keahlian bahasa inggris alumni sebanyak $2 \%$. Hal ini berarti bahwa pengguna alumni kurang puas dengan kinerja alumni IESP yang berkaitan dengan keahlian bahasa inggris, dimana pengguna alumni IESP memberikan penilaian cukup terhadap bahasa inggris alumni.
Tanggapan pengguna terhadap keahlian IT alumni IESP memiliki penilaian sebanyak $12 \%$ alumni IESP memiliki keahlian IT yang sangat baik (SB), tanggapan pengguna terhadap keahlian IT alumni IESP memiliki penilaian sebanyak $82 \%$ alumni IESP memiliki keahlian IT yang baik (B). Sedangkan tanggapan pengguna alumni terhadap keahlian IT alumni yang memberikan nilai Cukup (C) sebanyak 6\% alumni, sedangkan tidak ada pengguna alumni IESP yang memberikan penilaian kurang (K) terhadap keahlian IT alumni. Hal ini berarti bahwa rata-rata alumni IESP memiliki kemampuan IT yang cukup baik, Tanggapan pengguna terhadap Komunikasi alumni IESP memiliki penilaian sebanyak 26\% alumni IESP memiliki Komunikasi yang sangat baik (SB), tanggapan pengguna terhadap Komunikasi alumni IESP memiliki penilaian sebanyak 74\% alumni IESP memiliki Komunikasi yang baik (B). Sedangkan tanggapan pengguna alumni terhadap Komunikasi alumni yang memberikan nilai Cukup (C) dan kurang (K) terhadap Komunikasi alumni tidak ada. Hal ini berarti bahwa rata-rata alumni IESP memiliki kemampuan IT yang cukup baik, dimana berarti bahwa komunikasi alumni IESP didunia kerja cukup komunikatif dalam pekerjaannya sehari-hari 
Tanggapan pengguna terhadap Kerjasama Tim alumni IESP memiliki penilaian sebanyak $24 \%$ alumni IESP memiliki Kerjasama Tim yang sangat baik (SB), tanggapan pengguna terhadap Kerjasama Tim alumni IESP memiliki penilaian sebanyak $74 \%$ alumni IESP memiliki Kerjasama Tim yang baik (B). Sedangkan tanggapan pengguna alumni terhadap Kerjasama Tim alumni yang memberikan nilai Cukup (C) sebanyak 2\% alumni, sedangkan tidak ada pengguna alumni IESP yang memberikan penilaian kurang (K) terhadap Kerjasama Tim. Hal ini berarti bahwa alumni IESP memiliki Kerjasama Tim yang cukup baik dan dapat bekerja dengan siapapun di lingkungan kerja. Tanggapan pengguna terhadap Pengembangan Diri alumni IESP memiliki penilaian sebanyak 16\% alumni IESP memiliki Pengembangan Diri yang sangat baik (SB), tanggapan pengguna terhadap Pengembangan Diri alumni IESP memiliki penilaian sebanyak 80\% alumni IESP memiliki Pengembangan Diri yang baik (B). Sedangkan tanggapan pengguna alumni terhadap Pengembangan Diri alumni yang memberikan nilai Cukup (C) sebanyak 4\% alumni, sedangkan tidak ada pengguna alumni IESP yang memberikan penilaian kurang (K) terhadap Pengembangan Diri.
Hal ini berarti bahwa alumni IESP memiliki Pengembangan Diri yang cukup baik.

\section{KESIMPULAN DAN SARAN}

\section{Kesimpulan}

1. Alumni IESP menumpuh masa studi dalam jangka waktu 4 tahun sebanyak 71\% alumni, hal ini berarti masa studi mahasiswa di jurusan IESP sebagian besar tepat pada waktu dan menjadi keberhasilan bagi program studi dalam mengelola jurusan IESP dan untuk masa tunggu alumni IESP untuk mendapatkan pekerjaan relatif singkat yaitu kurang dari 6 bulan sebanyak 76\% alumni, hal ini berarti alumni IESP sangat cepat terserap di dunia kerja baik yang bekerja di instansi pemerintahan, swasta, maupun sebagai berwirausaha.

2. Penilaian pengguna alumni terhadap kinerja lulusan (alumni) program studi IESP dimana kinerja alumni yang paling tinggi menurut pengguna alumni yang memberikan nilai sangat baik (SB) adalah Komunikasi Alumni oleh alumni sebanyak $26 \%$ pengguna, sedangkan pengguna yang memberikan nilai baik (B) tertinggi untuk Penggunaan IT Alumni dengan nilai baik (B) sebanyak $82 \%$

3. Alumni IESP sebagian besar bekerja pada perusahaan swasta nasional 
terutama pada lembaga keuangan seperti perbankan, asuransi perusahaan pembiayaan dan lembaga keuangan lainnya yang mencapai $66 \%$, hal ini mengindikasikan bahwa alumni IESP bekerja pada bidang yang sesuai dengan keahlian yang mereka peroleh pada saat kuliah dulu, terutama keahlian yang mereka peroleh dari mata kuliah keahlian seperti mata kuliah bank lembaga keuangan lainnya, ekonomi moneter, ekonomi industry dan mata kuliah keahlian lainnya. Sedangkan alumni yang bekerja sebagai wiraswasta sebanyak 18\%, pegawai BUMN sebanyak orang $8 \%$, PNS $2 \%$ dan alumni yang bekerja sebagai honorer sebanyak $6 \%$.

\section{Saran}

1. Bagi pengelola program studi (Jurusan) IESP sebaiknya menambah SKS untuk mata kuliah yang dianggap penting yang sangat dibutuhkan oleh alumni didunia kerja seperti mata kuliah Bahasa Inggris agar alumni mendapatkan bekal dan keahlian yang cukup untuk dapat bersaing didunia kerja.
2. Jurusan IESP sebaiknya mengarahkan mahasiswa untuk mengikuti atau menjadi anggota English studi club (ESC) Fakultas Ekonomi dan Bisnis agar kemampuan bahasa inggris mahasiswa IESP dapat terasah dengan baik dan dapat berkomunikasi dengan baik juga

3. Fakultas melalui PD 3 sebaiknya memaksimalkan dan memberikan fasilitas kepada kelompok studi bahasa inggris untuk memperbanyak diskusi, workshop dan pelatihan-pelatihan yang berkaitan dengan pengembangan kemampuan bahasa inggris bagi mahasiswa terutama mahasiswa IESP karena dari penelitian tracer studi ini terlihat bahwa mata kuliah bahasa inggris sangat dibutuhkan didunia kerja.

4. Fakultas harus selalu mengadakan workshop kurikulum untuk kebutuhan alumni IESP didunia kerja, terutama mata kuliah dimana banyak alumni bekerja di bidang tersebut seperti mata kuliah bank dan lembaga keuangan, mata kuliah kebanksentralan dan mata kuliah lain yang berhubungan dengan perbankan dan lembaga keuangan lainnya.

\section{DAFTAR PUSTAKA}

Anonim. 2007. Ilmu Dan Aplikasi Pendidikan, edisi pertama. Jakarta. PT Imperial bhakti utama 
Mariyanti,1998, Penelusuran kesesuaian program studi dengan bidang pekerjaan para lulusan fakutas ekonomi Universitas Trisaksi jurusan ekonomi pembangunan tahun 1997/1998.FE-Univeritas Trisaksi.Jakarta.

Suharti \& Laksono,2012, "Studi penelusuran terhadap alumni program studi manajemen fakultas ekonomika dan bisnis universitas Kristen satya wacana". FEB-Universitas Kristen Satya Wacana.Jogjakarta.

Soemantri,Dkk (2010) Dengan Judul "Kajian Relevansi Lulusan Jurusan Pendidikan Geografi UNY Tahun 2005 - 2009",Universitas Negeri Yogyakarta.

Salsabila,Sari, 2013, Relevansi Kurikulum Jurusan Kurikulum Dan Teknologi Pendidikan Dengan Dunia Kerja (Studi Kasus Guru Tik, Dinas Pendidikan, Dan Lembaga Diklat). Skripsi UNS Semarang

Schomburg, Harald (2003). Handbook for Graduate Tracer Study. Moenchebergstrasse Kassel, Germany: Wissenschaftliches Zentrum für Berufs- und Hochschulforschung, Universität Kassel

Sugiyono. 2005.Statistik untuk Penelitian.Bandung: CV Alfabeta

Universitas Mataram. 2010. Kurikulum 2010. Mataram: UNRAM Press

Universitas Mataram. (2010 - 2013) Buku Wisuda, Universitas Mataram 